\title{
Shareholder Reactions to Judicial Decisions Affecting Sales Tax and Direct Marketing Activities
}

Kimberly G. Key, (E-mail: keykimb@auburn.edu), Auburn University

Nell Adkins, (E-mail: nadkins@www.business.uab.edu), University of Alabama at Birmingham

\begin{abstract}
This study examines shareholder reactions to judicial decisions that affect sales tax collection by firms conducting direct marketing activities. Abnormal returns are measured for four dates related to the 1992 United States Supreme Court decision in Quill. Results do not indicate statistically significant returns, but some tests indicate differential firm reactions. Therefore, abnormal returns are also calculated for subsets of firms that are relatively more affected by the court decisions, but no statistically significant results are obtained. More research is needed in order to determine whether sales tax avoidance is a meaningful incentive for mail order and Internet purchasers.
\end{abstract}

\section{Introduction}

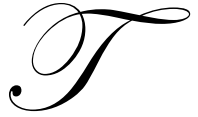

his study examines shareholder reactions to court decisions that affect sales tax collection by firms conducting direct marketing activities. A long judicial history holds that out of state businesses lacking sufficient business activities within a state, i.e., businesses without "nexus" to the state, do not have a responsibility to collect and remit the state's sales tax on purchases shipped to in-state customers (e.g., National Bellas Hess, Inc. v. Department of Revenue of Illinois (1967) and Quill Corporation v. North Dakota (1992)). Further, no other state would have jurisdiction to collect a sales tax related to such a transaction because the sale is deemed to occur at the point of delivery. The nexus requirement with respect to sales tax collection obligations is of particular importance to direct marketers because many are located in a single or only a few states but generate mail order sales in numerous states.

The research question addresses the economic issue of consumer sensitivity to taxes by assessing shareholder reactions to judicial decisions that affect mail order firm sales tax collection obligations. The mail order setting is theoretically similar to that of geographical border studies that show sensitivity to tax rates is large for consumers living along state borders (e.g., Fox, 1986). However, the mail order setting differs because consumers' tax-induced behavior does not depend on consumers living close to a border. Instead, any consumer in the state can place an order with an out of state firm and avoid imposition of sales tax by the vendor. This study is of interest because it provides evidence on the perceived importance of a tax avoidance opportunity in the mail order setting, a setting not previously considered in the state border research. The study's use of stock price data assesses the extent to which shareholders perceive the mail order tax collection issue affects firm value. The study extends research that shows sales taxes have significant effects on Internet purchases (Goolsbee, 2000), which are also transactions in which state sales taxes can be avoided, and research that shows Supreme Court decisions are value-relevant (Dhaliwal and Erickson, 1998).

The inquiry is also of interest because direct marketing industry group members disagree about the effect of possible increases in firm sales tax collection obligations. Dow Jones Online News (1997) reports that analysts have debated how the sales tax would affect customers. Some argue that the convenience of mail order shopping would 
Readers with comments or questions are encouraged to contact the authors via email.

offset the extra [tax] charge, but others predict a decline in catalog sales. Results in this study can potentially contribute useful information to the ongoing public policy debate on mail order and Internet sales tax collection. For example, administrative and legislative proposals are being considered that would implement sales tax collection obligations on mail order sellers regardless of nexus. ${ }^{1}$ This study's evidence on firm value effects could be helpful in these administrative deliberations.

In order to assess shareholder perceptions, abnormal returns are calculated at key judicial dates surrounding the 1992 United States' Supreme Court decision in Quill. The Quill decision maintained the status quo for nexus standards. Sample firms are identified using relevant SIC codes. Additional tests are conducted on two subsets of sample firms for which the court decisions are considered particularly important. One subset of firms is formed based on the number of states with which a firm has nexus. Firms with relatively few in-state contacts (i.e., that have nexus with only one or a few states) are most affected by the judicial decisions because these firms continued to avoid sales tax collection obligations in most states. The second subset of firms is identified based on whether the firm is involved strictly in selling taxable products directly to consumers. A greater portion of the business of these firms, as opposed to firms that operate in diversified lines of business, is affected by the court decisions. For both of these subsets of firms the expectation is that the magnitude of the predicted positive market reaction will be greater. Results show no statistically significant market reaction at four event dates for the full sample. However, there is evidence of differential reactions among sample firms, which is subject to further investigation. However, when the sample is partitioned based on the relative importance of the Quill decision to sample firms, there are also no statistically significant market reactions. Further research is needed to determine what, if any, effect potential sales tax obligations have on mail order and Internet purchasers. There has been increased visibility of sales tax issues since the Quill decision due to the growth of the Internet and developments such as the Internet Tax Freedom Act, yet there is very little evidence to show whether taxes affect purchasers.

The paper proceeds by describing the institutional setting of the study and stating the hypotheses. Section 3 discusses the motivation for the study and prior research. Research design is presented in Section 4, and Section 5 reports the results. Concluding remarks are made in Section 6.

\section{Sales Tax Issues and the Quill Decision}

\section{Institutional Setting and Hypotheses}

Sales tax is imposed on the purchase price of most retail goods. The purchaser incurs the tax, but if the seller has nexus with the purchaser's state, the seller has an agency-type obligation to the state to collect the sales tax from the customer and remit it to the state. Nexus is a concept that defines the minimum level of in-state business activity that must exist in order for the state to have jurisdiction over, and taxing authority with respect to, the business. Therefore, a business without nexus to a state can make sales to customers in that state without an obligation to collect and remit sales tax. ${ }^{2}$ These sales tax nexus issues are particularly relevant to direct marketers as the nature of the business is such that many firms generate sales in states with which the firms do not have nexus. However, some firms have operations in all or nearly all fifty states, which creates nexus, so the firms are obligated to collect sales tax from most of their mail order customers. ${ }^{3}$

Nexus standards have Constitutional underpinnings in the Commerce Clause and Due Process Clause, which impose limits on taxing powers of states. In Quill, North Dakota sought to impose tax collection responsibilities on an out of state mail order office supply business that had no offices, warehouses, or employees in the state. The facts are indistinguishable from those in a 1967 U.S. Supreme Court decision, National Bellas Hess, but the North Dakota state court did not follow the precedent of the 1967 case stating that "tremendous social, economic, commercial, and legal innovations of the past quarter century... rendered the [1967] holding obsolete." The U.S. Supreme Court overruled the state court and maintained the existing physical presence standard for nexus. Thus, vendors who solicit business through catalogs, flyers, advertising in national periodicals, and telephone calls and who deliver merchandise to customers by mail or common carrier lack "substantial nexus" with the state and may not be required by the state to collect and remit customer sales tax (Quill, 1992). 
Key dates with respect to the Quill decision are summarized in Table 1. The May 26, 1992, U.S. Supreme Court decision is described as one of the most significant business cases of the term and was closely watched by industry and consumer groups (Barrett, 1992). The ruling was declared a victory for mail order firms by many observers (e.g., Barrett, 1992; Elsasser, 1992; Savage, 1992). The hypothesis of a positive stock market reaction to the Quill decision is investigated. Other relevant dates reported in Table 1 are also investigated. The predicted sign for the May 7, 1991, date is negative because the North Dakota Supreme Court, in overruling the state District Court, found in favor of the state over Quill Corp. Reactions on dates of the U.S. Supreme Court decision to grant certiorari and the hearing of the case are predicted to be positive because the information raises the possibility of the Supreme Court overruling the North Dakota decision.

Table 1

Key Dates with Respect to Quill Decision

\begin{tabular}{|c|c|c|}
\hline $\begin{array}{l}\text { Date } \\
\text { (predicted stock market } \\
\text { reaction) }\end{array}$ & Event & Press Coverage $^{1}$ \\
\hline $\begin{array}{l}\text { May } 7,1991 \\
\text { (negative) }\end{array}$ & $\begin{array}{l}\text { Supreme Court of North Dakota finds in favor } \\
\text { of state by reversing state District Court }\end{array}$ & one article on May 13, 1991 \\
\hline $\begin{array}{l}\text { October 7, } 1991 \\
\text { (positive) }\end{array}$ & $\begin{array}{l}\text { United States Supreme Court grants writ of } \\
\text { certiorari }\end{array}$ & $\begin{array}{l}\text { one article on October 7, } 1991 \\
\text { five articles October 8, } 1991\end{array}$ \\
\hline $\begin{array}{l}\text { January 22, } 1992 \\
\text { (positive) }\end{array}$ & $\begin{array}{l}\text { case argued before United States Supreme } \\
\text { Court }\end{array}$ & $\begin{array}{l}\text { two articles on January 21, } 1992 \\
\text { one article January 22, } 1992 \\
\text { one article January 23, } 1992 \\
\text { Wall Street Journal article January 24, } 1992\end{array}$ \\
\hline $\begin{array}{l}\text { May 26, } 1992 \\
\text { (positive) }\end{array}$ & $\begin{array}{l}\text { United States Supreme Court finds in favor of } \\
\text { Quill Corp. by reversing Supreme Court of } \\
\text { North Dakota }\end{array}$ & $\begin{array}{l}\text { one article May 26, } 1992 \\
\text { four articles May 27, } 1992 \\
\text { Wall Street Journal article May 27, } 1992 \\
\end{array}$ \\
\hline
\end{tabular}

Additional hypotheses are investigated because there are differences across firms in the relative importance of the court decisions. The first test is based on the number of states with which firms have nexus and, therefore, sales tax collection obligations. The court decision does not affect all firms in a consistent manner. For example, a firm with nexus to all fifty states that appropriately collects and remits sales tax to all the states should have a reaction of lesser magnitude than a firm that has nexus with fewer states. ${ }^{4}$ The formal prediction is that the magnitude of the predicted positive stock market reaction is greater for firms operating in relatively fewer states (i.e., for firms that avoid the collection obligation in many states due to a lack of nexus). ${ }^{5}$

The second test is based on the extent to which the firm is involved strictly in the sale of taxable products directly to consumers. Sample firms that engage strictly in consumer product sales, i.e., firms that are not diversified into unrelated lines of business, are most affected by the court decisions. To the contrary, firms that are diversified and that conduct only a portion of business oriented toward consumer products are less affected. Further, mail order prescription drug firms should be relatively less affected as well because the drugs are an exempt item for every, or nearly every, state's sales tax base. The formal prediction is that magnitude of the predicted positive stock market reaction is greater for firms that operate with a primary business related to taxable sales of consumer products.

\section{Conditions Necessary for Stock Market Reaction}

There are several conditions or assumptions that must be met in order for statistically significant abnormal returns to be detected in any event study. The necessary conditions in this study include the following: 
1. The specified event dates provide unexpected information to the market that is processed and impounded in stock prices very quickly.

2. Shareholders believe consumers are affected by sales tax rate differentials, and therefore, that firm sales revenue is affected by sales tax collection obligations.

3. The sample selection adequately identifies and partitions firms with mail order operations.

A complete surprise cannot be present at all four dates in this study. For example, once the Supreme Court granted a writ of certiorari, market participants anticipate the case will be heard (the third date) and a decision rendered (the fourth date). Nonetheless, it is reasonable to assume that there exists some uncertainty with respect to any court decision and the timing of that decision. To the extent information is new, it can be impounded in price fairly quickly because the relevance of the case to affected firms is relatively clear. The decision was made with respect to a specified business activity that is visible in the economy. Shareholder beliefs are not known, but industry analysts call the ruling a victory. Further, research discussed in the next section shows a strong relation between sales tax and consumer purchase behavior, which provides empirical support for the assumption that shareholders believe such a relation, is relevant to direct marketers.

With respect to the third assumption, a specific SIC code is used to identify firms, $5961=$ mail order houses. However, if firms that engage in direct marketing activities do not disclose this SIC code as either primary or secondary, the sample is missing affected firms, and the missing firms are in the market data that serve as a benchmark for the abnormal return calculations. Further, if sample firms identify themselves with the SIC Code = 5961 but do not conduct substantial direct marketing activities, the power of the tests to detect abnormal returns, if in fact they exist, is diminished. The additional tests that partition the sample counteract this possibility, and therefore, are more powerful tests of the abnormal returns hypothesis.

\section{Motivation and Prior Research}

Prior research shows that differential sales tax rates along state borders distort the location of retail sales along those borders (e.g., Fox [1986] and Walsh and Jones [1988]). In these settings consumers are predicted to shop in lower tax rate jurisdictions when the tax savings is greater than transportation costs and opportunity costs of travel time to obtain the tax savings. Walsh and Jones (1988) report that work in this area shows behavioral responses such that a $1 \%$ increase in the sales tax rate is associated with sales declines ranging from 1 to $10 \%$. This research is relevant to this study because shareholders are assumed to believe that similar tax-induced behavior exists for mail order firm customers. To the extent the Quill judicial decisions maintain an environment in which there are tax rate differentials for local versus mail order shopping, shareholder reactions are expected to be positive.

Goolsbee (2000) examines the effects of sales taxes on Internet commerce, a setting theoretically similar to the geographical border studies. Internet sales tax issues are very similar to the traditional mail order setting issues where orders are phoned or mailed. The sales tax collection obligations do not depend on the customer ordering mechanism. If the firm has nexus with a state, the firm is obligated to collect sales tax from the customer. Results in Goolsbee (2000) show that people who live in high sales tax locations are more likely to make purchases using the Internet. He reports that applying existing sales taxes to Internet commerce would reduce the number of online buyers by $20-25 \%$ and spending by $25-30 \%$ (Goolsbee, 2000). A limitation of the study is that the data do not reveal whether consumers' Internet transactions actually were subject to sales tax. He assumes all Internet transactions avoid sales tax (page 7). This assumption is almost certainly violated, but the extent of the violation cannot be assessed. ${ }^{6}$ The implication of this violation is that the estimates of potential reductions in online buying are likely overstated to some degree. This study differs from Goolsbee (2000) by examining shareholder perceptions and by including data that reflect the extent to which firms are affected by the court decisions. Shareholder perceptions are of interest because decision making by these investors affects firm value, and firm managers and policy makers can benefit from information related to firm value effects with respect to sales tax issues.

The study also is motivated by research on judicial decisions investigated recently by Dhaliwal and Erickson (1998). They document wealth effects related to three court decisions regarding the deductibility of tax amortization of intangible assets. Their hypothesis is that stockholders will react negatively to court decisions that 
jeopardize amortization expense deductions and positively to decisions in favor of the deductions. The samples they investigate are firms engaged in leveraged buyouts and a set of large, diversified firms with intangible assets. This study differs from Dhaliwal and Erickson (1998) because this study's sample firms are directly affected by the Quill decision; therefore, there can be greater confidence that a detected reaction is due to the court decision. However, unlike the tax amortization issue addressed in these prior studies, sales tax collection does not directly affect firm tax expense, liabilities and cash flows, which makes a reaction less likely. Instead, the predicted market reaction in this study derives from the assumption that shareholders believe consumer purchases, and therefore, firm revenues would decline if firm sales tax collection obligations were expanded. Also, it is a reasonable to assume that ability of firms to raise prices would be diminished if customers have just experienced an overall cost increase due to the imposition of new sales taxes.

Finally, the study is of interest because there are conflicting viewpoints on direct marketer sales tax collection issues. A representative of Eddie Bauer says the requirement to collect mail order sales tax from customers in states with which Eddie Bauer has nexus "caused only a 'very slight' drop in sales," but the CEO of a clothes maker in New Mexico says, "Charging the tax could 'severely impact' business," (Milbank, 1997). William Dean, a catalog consultant says, "The bottom line is convenience, and the tax isn't much of a factor," yet retail consultant Kurt Barnard states, "Customers will think twice before ordering a costly item from a catalog if a sales tax is to be added" (Wolf, 1997). The actual effect on firm revenue if sales tax collection obligations are expanded cannot be determined directly, but this study attempts to provide indirect evidence in the form of shareholder perceptions.

\section{Research Design}

Shareholder reaction is assessed with well-developed event study methodology. In this study residuals from regression equations used for hypothesis testing are expected to exhibit cross-sectional correlation because each event occurs on the same calendar date for all affected firms and because firms have industry in common. Binder (1985, 167-168) proposes the Multivariate Regression Model (MVRM) as a solution to these inherent difficulties. Consistent with prior research (Schipper and Thompson, 1983; Pownall, 1986; Scholes, Wilson, and Wolfson, 1990), the MVRM used in this study follows the seemingly unrelated regressions (SUR) method of Zellner (1962) using generalized least squares estimation.

Assumptions of the SUR approach are that the disturbance terms are independent and identically distributed within each equation, but disturbance term variances differ across equations, and that, across equations (firms), the contemporaneous covariances of the disturbances are nonzero. The major advantages of the MVRM approach over a more traditional event study approach are in hypothesis testing; heteroscedasticity across equations and contemporaneous dependence of the disturbances is explicitly incorporated into the hypothesis tests. The model used assumes that the process generating stock returns is appropriately described by the market model and is shown in the following equations:

$$
\begin{gathered}
R_{1 t}=\alpha_{1}+\beta_{1} R_{m t}+\lambda_{1 j} D_{j t}+\varepsilon_{1 t} \\
R_{2 t}=\alpha_{2}+\beta_{2} R_{m t}+\lambda_{2 j} D_{j t}+\varepsilon_{2 t} \\
\ldots \quad \ldots \quad \ldots \\
\ldots \\
R_{N t}=\alpha_{N}+\beta_{N} R_{m t}+\lambda_{N j} D_{j t}+\varepsilon_{N t}
\end{gathered}
$$

Where,

$\mathrm{R}_{\mathrm{it}}=$ return on stock of firm $\mathrm{i}$ on day $\mathrm{t}$,

$\mathrm{R}_{\mathrm{mt}} \quad=$ the equally weighted market return on day $\mathrm{t}$,

$\mathrm{D}_{\mathrm{jt}}=1$ if day $\mathrm{t}$ is a judicial event day, 0 otherwise,

$\alpha_{i} \quad=$ estimated intercept for firm i,

$\beta_{i} \quad=$ estimated market return beta for firm $\mathrm{i}$, 


$$
\begin{aligned}
\lambda_{i j} & =\text { event intercept }, \\
\varepsilon_{i t} & =\text { residuals, } \\
\mathrm{t} & =1 \text { to } \mathrm{t}, \text { the number of days in the event estimation period }
\end{aligned}
$$

The abnormal returns for the U.S. Supreme Court's Quill decision and next day's Wall Street Journal coverage are summed to obtain a two-day abnormal return for each firm. A positive abnormal return ( $\lambda$ ) around the Quill decision is consistent with the hypothesis that market participants believe the Court's decision is value-relevant, good news. The sample is identified by screening in the CRSP database for SIC codes that comprise three-digit Nonstore Retailers, 596. Compact Disclosure is also searched for SIC code 5961, Mail Order Houses, and additional firms are identified because, unlike CRSP, the database contains both primary and secondary SIC codes. A confounding event search was performed for all four dates using the Dow Jones News Retrieval Service with the result that some sample firms are excluded for some of the test dates.

The additional hypotheses assess whether the magnitude of predicted abnormal returns is greater for two subsets of sample firms, firms operating in relatively fewer states and firms that are strictly involved in sales of taxable consumer products. Data to test the nexus hypothesis are gathered primarily from the Properties disclosure in SEC Form 10-K. The presence of property in a state creates nexus with the state, so this property information is a good indicator of nexus. Disclosures are not consistent between sample firms, so calculating a precise number of nexus states is not feasible. Instead, the sample firms are grouped by low and high for this test. Data to test the consumer products hypothesis are also gathered from the SEC Form 10-K with particular emphasis on the business description at the beginning of the Form 10-K.

\section{Results}

Table 2 provides descriptive information with respect to the sample. Panel A reconciles the number of firms initially identified using SIC code searches in the CRSP and Compact Disclosure databases with the number in the final sample. Approximately 50 firms are available for testing abnormal returns at the four event dates. Panel B reveals that firm distribution across stock exchanges is greater and nearly even for NYSE and NASDAQ; fewer firms trade on AMEX. Size information in Panel $\mathrm{C}$ shows that across the four event dates, the mean market value of equity is in the $\$ 600$ millions. There is a substantial range of firm sizes with the smallest firm-year market value of equity equal to $\$ 1$ million and the largest $\$ 10$ billion.

Table 3 reports the results of the two-day abnormal return calculations. ${ }^{7}$ Mean parameter values are reported in the last column. The first hypothesis tests whether there is an abnormal return on the specified event dates. The null hypothesis of no market reaction is not rejected for any event dates. As described in Section 3.1 and footnote 5, there are several possible reasons insignificant results are obtained. Event dates might not provide new information to the market, or the information could be inconsistent for sample firms. Also, the court decisions could be considered a step in a longer process, i.e., shareholders could anticipate that legislative action would follow and make the decision moot. If so, the court decision would have reduced long-term implications. Finally, the sample selection criteria may not capture all firms with substantial mail order sales

Two additional hypotheses are also tested. Hypothesis 2 assesses whether some sample firms have abnormal returns, and Hypothesis 3 tests whether there are differences among sample firms in the abnormal returns. On two dates, October 7, 1991, and May 26, 1992, the results for these tests are not statistically significant. Therefore, for the U.S. Supreme Court decision date, no statistically significant results are obtained for any of the three hypotheses. On the other two dates, May 7, 1991, and January 22, 1992, the results show statistically significant results for both Hypotheses 2 and 3. These results suggest that there are between-firm differences in stock market reactions. The May 7 date has approximately the same number of positive and negative abnormal returns ( 24 and 26, respectively), but on the January 22 date nearly sixty percent of firms (28 out of 47 ) have a negative abnormal return. 
Table 2

Sample Information

Panel A: Sample Derivation

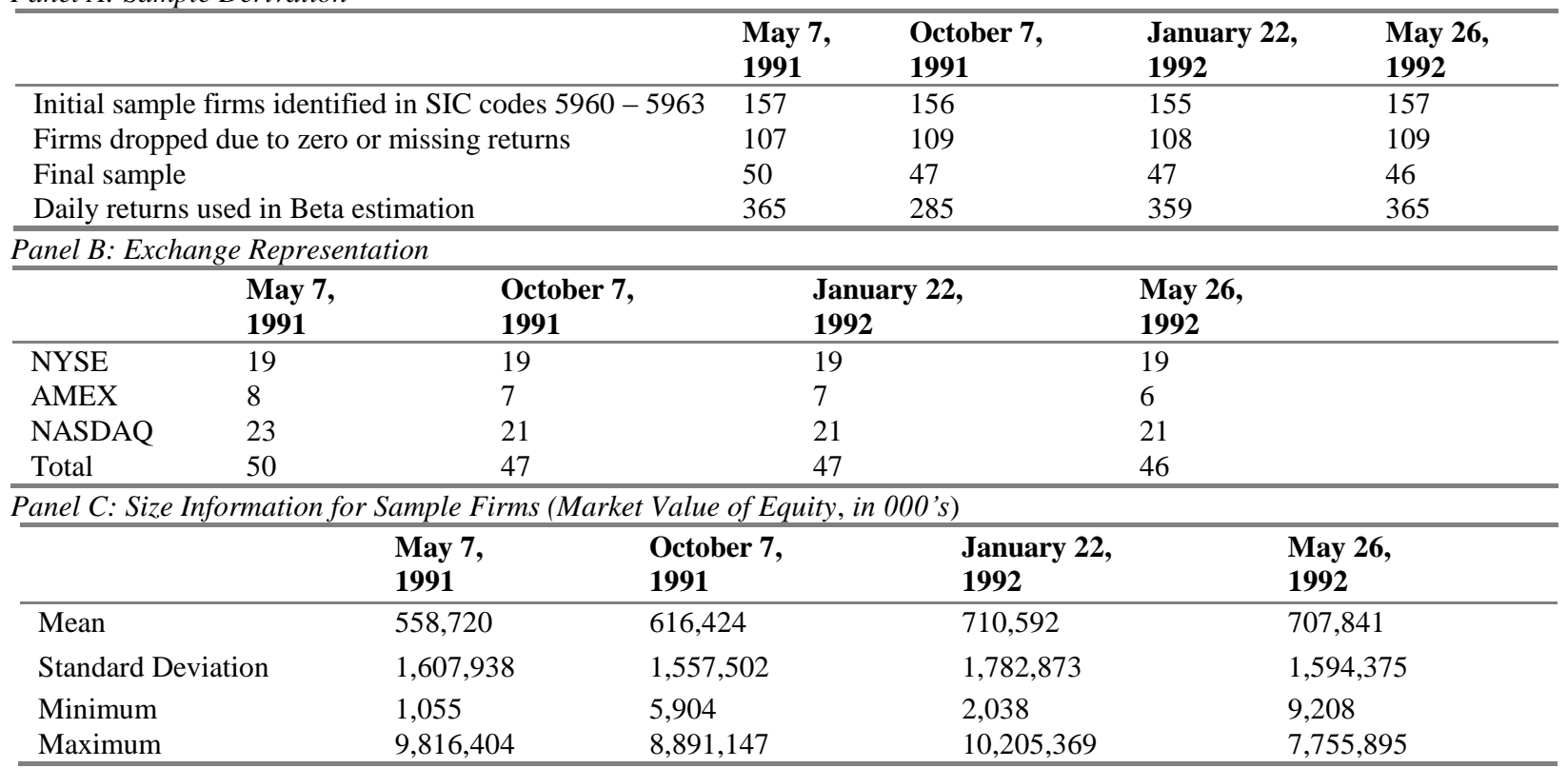

Table 3

Abnormal Return Hypothesis Testing

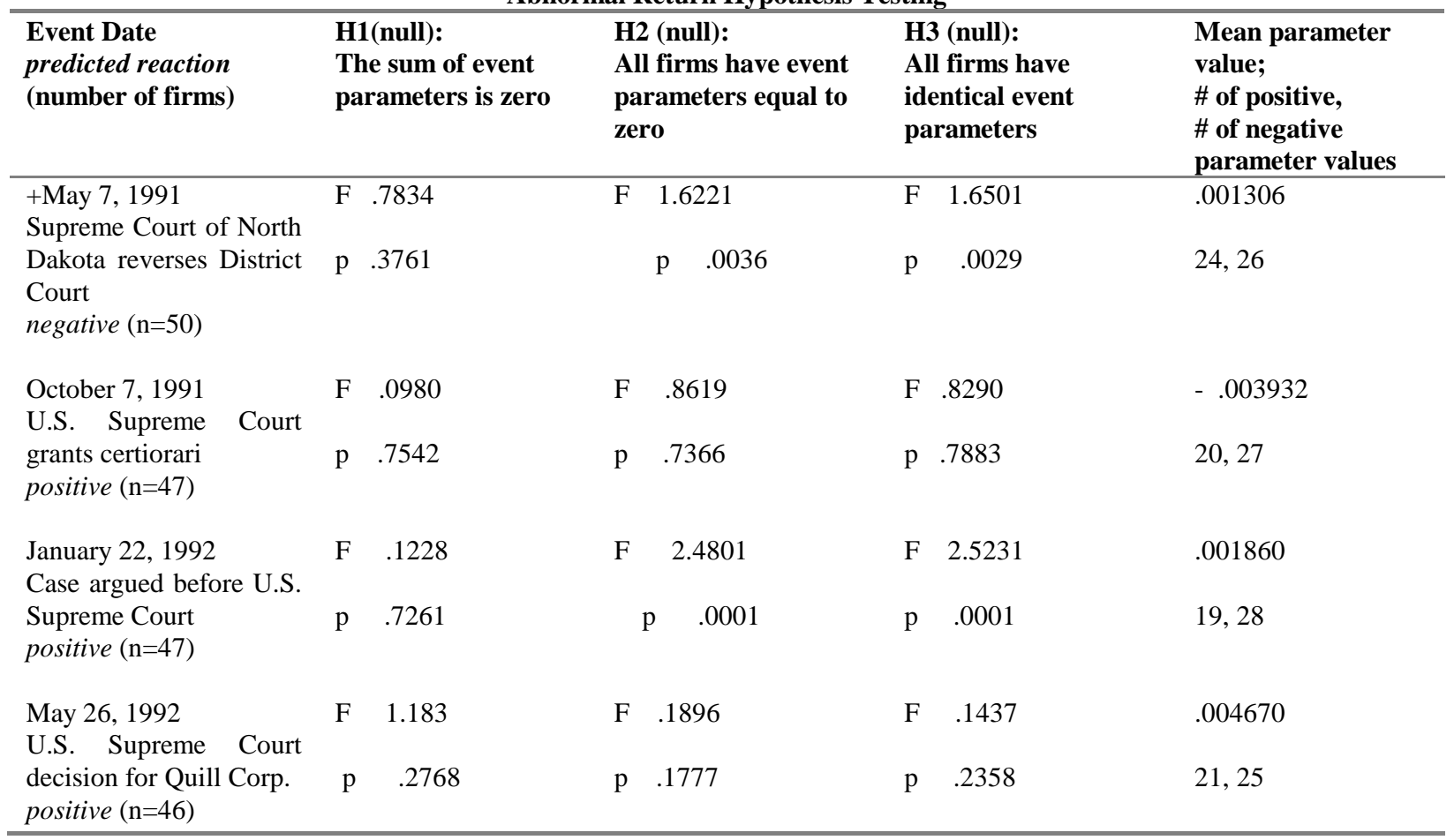

$\mathrm{F}=\mathrm{f}$-statistic; $\mathrm{p}=\mathrm{p}$-value

Regression equation: 
The second research hypothesis, that firms with a higher degree of nexus with states have relatively more positive stock market reactions, is tested by calculating abnormal returns for a subset of 29 firms. Results (not reported) are qualitatively the same as the main tests. The third research hypothesis identifies 32 firms particularly oriented toward taxable consumer products also has results (not reported) that are qualitatively the same as the main tests. Despite that the full sample results suggest differential within-sample abnormal returns, the two sample partitions do not explain the differential.

\section{Conclusion}

The purpose of this study is to provide evidence on shareholder perceptions of the effect of sales tax collection obligations on firms with direct marketing activities. Results are not consistent with shareholders perceiving that the sales tax issue is relevant with respect to their investments in the stock of affected firms. Goolsbee's (2000) result suggest that sales taxes are a substantial impediment to Internet commerce, and earlier research finds sensitivity to sales taxes at geographical borders (e.g., Fox, 1986), but there appears to be little other evidence regarding this important current political issue. One reason that there is not extensive research is that there are not numerous opportunities to study these issues. For example, studies of market returns require that important and unexpected events occur, but these occurrences are infrequent. In addition, state-level data are difficult to obtain. This study takes advantage of an infrequent opportunity to conduct well-designed empirical tests with respect to sales tax issues. Despite the lack of statistically significant findings, the research merits some attention because there is so little ability to investigate these research questions.

\section{Suggestions for Future Research}

Future research that is directly related to this study could employ additional methods to examine the importance of the connection between sales tax and mail order or Internet sales. For example, a behavioral study could use identical products and manipulate whether sales tax would apply to a purchase of the product. Subjects would then be asked how likely they are to buy the products. In addition, the broader question in this study addresses the economic issue of consumer sensitivity to taxes. Future research could investigate the effect of other types of taxes on decision making. For example, differences in property taxes between two cities could affect business location decisions.

\section{Endnotes}

1. For example, the Direct Marketing Association (1997) has proposed an administrative agreement on sales tax collection.

2. Technically, a customer who makes purchases on which no sales tax is paid has a use tax obligation to the state. Theoretically, then, the use tax fully captures sales tax that is not collected by out of state businesses. However, use tax collections are far below the sales tax amounts for which the use taxes should substitute. The reasons are likely a combination of (1) a lack of knowledge of use tax obligations on the part of the purchaser and (2) a low probability that an informed decision not to comply with use tax will be detected and punished. Estimates are that $\$ 3$ billion in potential tax is not being collected (Milbank, 1997).

3. For example, sample firm Williams Sonoma home and kitchen products are sold both by catalog and in retail store outlets throughout the United States. The in-state retail operations create nexus with a state, so mail order sales to customers within the state are subject to sales tax collection and remittance by Williams Sonoma.

4. In fact, managers and shareholders of firms with nexus to nearly all states could prefer that sales tax collection obligations be expanded because competitors that do not have to collect sales tax due to existing nexus standards could be perceived to have competitive advantages. Population data also affect an analysis based on the number of nexus states. Even if a firm has nexus with only a single state, if the state is highly populated, the portion of sales subject to sales tax collection is higher than if the state is sparsely populated. Population data are easily obtained. Nonetheless, no population data are used because nexus data are not precise enough to identify exactly the states with which sample firms have nexus. 
5. This prediction assumes market participants understand the nexus issue and have information regarding firm-state nexus situations.

6. Every firm has nexus with at least one state, and the majority of states imposed sales and use tax. Therefore, firm sales are very likely to be subject to sales tax collection in at least one state.

7. Sensitivity analysis is conducted and includes the calculation of five-day returns with no qualitative difference in the results.

8.

\section{References}

1. Barrett, P. 1992. Justices Rebuff States on Taxing Mail Order Sales, The Wall Street Journal, Dow Jones \& Company, Inc., May 26, 1992.

2. Binder, J. 1985. Measuring the Effects of Regulation With Stock Price Data. Rand Journal of Economics 16 (summer): 167-183.

3. Dhaliwal, D. and M. Erickson. 1998. Wealth Effects of Tax-Related Court Rulings. The Journal of the American Taxation Association 20 (spring): 21-48.

4. Direct Marketing Association. 1997. Administrative Agreement on Multistate Tax Compliance for Collection of Sales and Use Tax by Marketers with Limited Presence in Participating States. Reported in State Tax Notes, September 30, 1997.

5. Dow Jones Online News. 1997. Talks Continue, But Catalog Sales Tax Issue Addles Customers. Dow Jones \& Company Inc., November 7, 1997.

6. Elsasser, G. 1992. High Court Clears Way for Taxing Mail Orders. Chicago Tribune, May 27, 1992.

7. Fox, W. 1986. "Tax Structure and the Location of Economic Activity Along State Borders," National Tax Journal 39: 387-401.

8. Goolsbee, A. 2000. In a World Without Borders: The Impact of Taxes on Internet Commerce. Quarterly Journal of Economics, forthcoming.

9. Milbank, D. 1997. Trade Group, Authorities in Talks to Settle Issue of Mail Order Tax. The Wall Street Journal, Dow Jones \& Company, Inc., November 7, 1997: B4.

10. National Bellas Hess, Inc. v. Department of Revenue of Illinois, 386 US 753, 87 S.Ct. 1389 (1967).

11. Pownall, G. 1986. An Empirical Analysis of the Regulation of the Defense Contracting Industry: The Cost Accounting Standards Board. Journal of Accounting Research 24: 291-315.

12. Quill Corporation v. North Dakota, 504 US 298, 112 S.Ct. 1904 (1992).

13. Savage, D. 1992. Court Voids State Mail Order Tax. Los Angeles Times, The Times Mirror Company, May 27, 1992.

14. Schipper, K., and R. Thompson. 1983. The Impact of Merger-Related Regulations on the Shareholders of Acquiring Firms. Journal of Accounting Research 21: 184-221.

15. Scholes, M., P. Wilson, and M. Wolfson. 1990. Tax Planning, Regulatory Capital Planning, and Financial Reporting Strategy for Commercial Banks. The Review of Financial Studies 3: 625-650.

16. Walsh, M. and J. Jones. 1988. "More Evidence on the "Border Tax" Effect: The Case of West Virginia, 1979-84," National Tax Journal 41: 261-265.

17. Wolf, R. 1997. Catalog Customers to Face a Costly Question: Sales Tax. Dow Jones Online News, Dow Jones \& Company, Inc., November 6, 1997.

18. Zellner, A. 1962. An Efficient Method of Estimating Seemingly Unrelated Regressions and Tests of Aggregation Bias. Journal of the American Statistical Association 57: 348-368. 
Notes 